\title{
The Aging Process of Human Neonatal Erythrocytes
}

\author{
LISA M. MATOVCIK, DANIEL CHIU, BERTRAM LUBIN, WILLIAM C. MENTZER,
} PETER A. LANE, NARLA MOHANDAS, AND STANLEY L. SCHRIER

\begin{abstract}
Division of Hematology, Stanford University Medical Center, Stanford, California 94305 [L.M.M., S.L.S.]; Bruce Lyon Memorial Research Laboratory, Oakland Children's Hospital, Oakland, California 94609 [D.C., B.L.]; and Departments of Pediatrics [W.C.M., P.A.L.] and Laboratory Medicine [W.C.M., N.M.], University of California, San Francisco, San Francisco, California 94143
\end{abstract}

\begin{abstract}
The red blood cell population of the human newborn is more heterogeneous than that of adults. To characterize this heterogeneity, red cells were separated on Stractan gradients into populations according to their density and, therefore, generally according to their age. Lipid content, phospholipid asymmetry, osmotic fragility, and deformability were measured. With increasing density, osmotic resistance and deformability decreased to a greater extent in the neonatal than the adult red cell. There was a marked loss of surface area throughout the life span of the neonatal red cell which was not accompanied by a parallel loss of membrane lipid. This apparent discrepancy could be explained at least in part by internalization of membrane lipid as a result of endocytosis, a process shown to be present in even the densest neonatal red cells. (Pediatr Res 20: 1091-1096, 1986)
\end{abstract}

\section{Abbreviations}

SAI, surface area index

MCV, mean cell volume

$\mathrm{MCH}$, mean cell hemoglobin

MCHC, mean cell hemoglobin concentration

BSKG, buffered saline with potassium and glucose

CHV, critical hemolytic volume

DI, deformability index

PC, phosphatidylcholine

PE, phosphatidylethanolamine

PS, phosphatidylserine

PI, phosphatidylinositol

SM, sphingomyelin

$\mathrm{DI}_{\max }$, maximum deformability

The shortened life span of neonatal red cells relative to that of adult red cells (1) is of intracorpuscular origin (2) and thus due to one or more of the many differences in composition and function that distinguish these two cell types. The actual properties that account for the premature destruction of neonatal red cells, however, are unknown. Linderkamp and Meiselman (3) have pointed out that the greater minimal cylindrical diameter of neonatal red cells may restrict their passage through the spleen, where prolonged sequestration could contribute to their de-

Received June 12, 1985: accepted June 4, 1986.

Correspondence and reprint requests should be addressed to Stanley L. Schrier, M.D., Chief, Division of Hematology, Stanford University Medical Center, Stanford, CA 94305.

This work was supported by Grants PO1 AM-32094, NRSA 5F32 HD 06633. and RO1 HL-27059 from the National Institutes of Health. creased life span. Another property of neonatal cells which may potentially have adverse rheological consequences is their loss of more than one-quarter of their surface area as they age in circulation (3-5). We have suggested that this property may be linked to the enhanced propensity of such cells to internalize plasma membrane through the process of endocytosis (5-7). In the current report, we further explore this possibility. To do so, we used the technique of Stractan density gradient centrifugation to prepare populations of buoyant (presumably young) and dense $(3,8,9)$ (presumably old) neonatal red cells. The amount of cell lipid was measured in each density fraction and the degree to which the loss in surface area was accompanied by loss of membrane lipid determined. Changes in phospholipid composition $(10,11)$ or asymmetry (12) were also sought. As an independent index of cell surface area (13), we measured red cell deformability in the ektacytometer (14). Our findings demonstrate that although the densest ("oldest") neonatal red cells have lost considerable surface area, they have not lost the expected equivalent quantities of membrane lipid, implying that at least some of the lipid must have been internalized rather than released into the plasma.

\section{MATERIALS AND METHODS}

Materials. Stractan was purchased from St. Regis Lumber Co., Libby, MT and prepared as previously described $(5,9)$. Cellulose (Sigmacell-50), $\alpha$-cellulose, cholesterol standard solution (CH-1), and bee venom phospholipase $\mathrm{A}_{2}$ were purchased from Sigma Chemical Co., St. Louis, MO. Sphingomyelinase $C$ was prepared as previously described (12).

Blood collection and density separation. Venous blood was collected from adult volunteers and cord blood was drawn from the placental vessels immediately upon delivery according to a protocol approved by the Stanford Medical Committee for the Protection of Human Subjects in Research. EDTA was used as the anticoagulant. The plasma was removed by centrifugation and the red cells washed three times in BSKG $(137 \mathrm{mM} \mathrm{NaCl}$, $2.7 \mathrm{mM} \mathrm{KCl}, 8.8 \mathrm{mM} \mathrm{Na}_{2} \mathrm{HPO}_{4} .7 \mathrm{H}_{2} \mathrm{O}, 1.5 \mathrm{mM} \mathrm{KH}_{2} \mathrm{PO}_{4}, 11.1$ $\mathrm{mM}$ glucose, $\mathrm{pH}$ 7.4). The diluted, washed blood was passed over a column of cellulose: $\alpha$-cellulose, 1:1 to remove white cells and platelets (15). An aliquot of unseparated red cells was removed and exposed to Stractan, then the rest of the red cells were separated according to their density on Stractan gradients as previously described $(5,9)$.

The total hemoglobin and $\mathrm{MCH}$ were measured with a Coulter Model S electronic cell counter. The MCHC was calculated by dividing the blood hemoglobin by the packed cell volume measured by spun hematocrit (16). The MCV was calculated from the $\mathrm{MCH}$ and $\mathrm{MCHC}$ rather than obtained directly from the counter, because the counter tended to underestimate the volume 
of larger red cells and overestimate the volume of smaller red cells in a manner similar to that described by Sutera et al. (17). The hemoglobin content of each fraction was determined using Drabkins' solution. The percentage of the total hemoglobin applied to the gradient that was present in each fraction was used as a measure of the relative size of that fraction.

Surface area. The critical hemolytic volume method described by Clark et al. (18) was used to estimate the plasma membrane surface area. After measurement of initial MCV and $\mathrm{MCH}$, the osmolarity at which red cells lysed was measured in a standard osmotic fragility assay. The critical hemolytic volume was then calculated, making the assumption that the red cell behaves as an osmometer. Changes in the osmotic coefficient of hemoglobin and in the volume that it occupies as the cells swell were taken into account in the calculations. The red cell surface area was estimated to be equivalent to that of a sphere whose volume was exactly that determined to be the critical hemolytic volume.

Osmotic fragility and osmotic gradient ektacytometry. Osmotic fragility of unincubated red cells was determined by the method of Dacie (19). The curves were generated from 12 points in which the red cells were lysed in $\mathrm{NaCl}$ solutions of decreasing osmolality. The osmolality of the solutions was measured by freezing point depression on an Osmette A, American Scientific Products, McGaw Park, IL.

Osmotic gradient ektacytometry was performed as previously described $(13,14,18)$. Briefly, red cells suspended in a viscous medium were subjected to a shear stress in the ektacytometer. A laser beam was passed throughout the cell suspension, generating a diffraction pattern whose degree of ellipticity corresponded to the deformation of the red cells. Measuring the deformability of red cells under constant shear stress, while the osmolarity of the suspending medium was gradually increased, provided information about cell surface area to volume relationships, cytoplasmic viscosity, and inherent membrane deformability.

Lipid analysis. Determinations of total erythrocyte cholesterol and phospholipid were made from lipid extracts prepared by the method of Rose and Oklander (20). Lipid phosphorous was quantitated by the method of Bottcher et al. (21) and cholesterol by the method of Zlatkis et al. (22). Stractan, used in density gradient separations, had no effect on either assay.

The organization of the phospholipid within the bilayer was examined by digesting the phospholipids in the outer portion of the membrane utilizing phospholipase $\mathrm{A}_{2}$ and sphingomyelinase $\mathrm{C}(12,23,24)$.

Endocytosis. Spontaneous endocytosis was evaluated by phase microscopy. Red cells $(2 \mu \mathrm{l})$ resuspended in isotonic buffer (hematocrit approximately $40 \%$ ) were added to $10 \mu \mathrm{l}$ of distilled water, allowing enough hemoglobin to leave the cell so that the vacuoles became visible as small, free, dark intracellular spheres.

\section{RESULTS}

Density separation of adult and neonatal red cells. Adult and neonatal red cells were separated by density into five fractions on discontinuous Stractan gradients. To illustrate the separation obtained, average red cell indices for each layer are shown in Table 1 . Neonatal red cells were distinguished by their wider $\mathrm{MCV}$ range from top fraction to bottom and by their higher density in the bottom fraction. The latter was readily evident by visual inspection of the gradient after centrifugation and is reflected by the higher MCHC of neonatal $(39.4 \mathrm{~g} / \mathrm{dl})$ compared to adult ( $34.8 \mathrm{~g} /$ liter) red cells.

Osmotic fragility and surface area. The osmotic fragility of

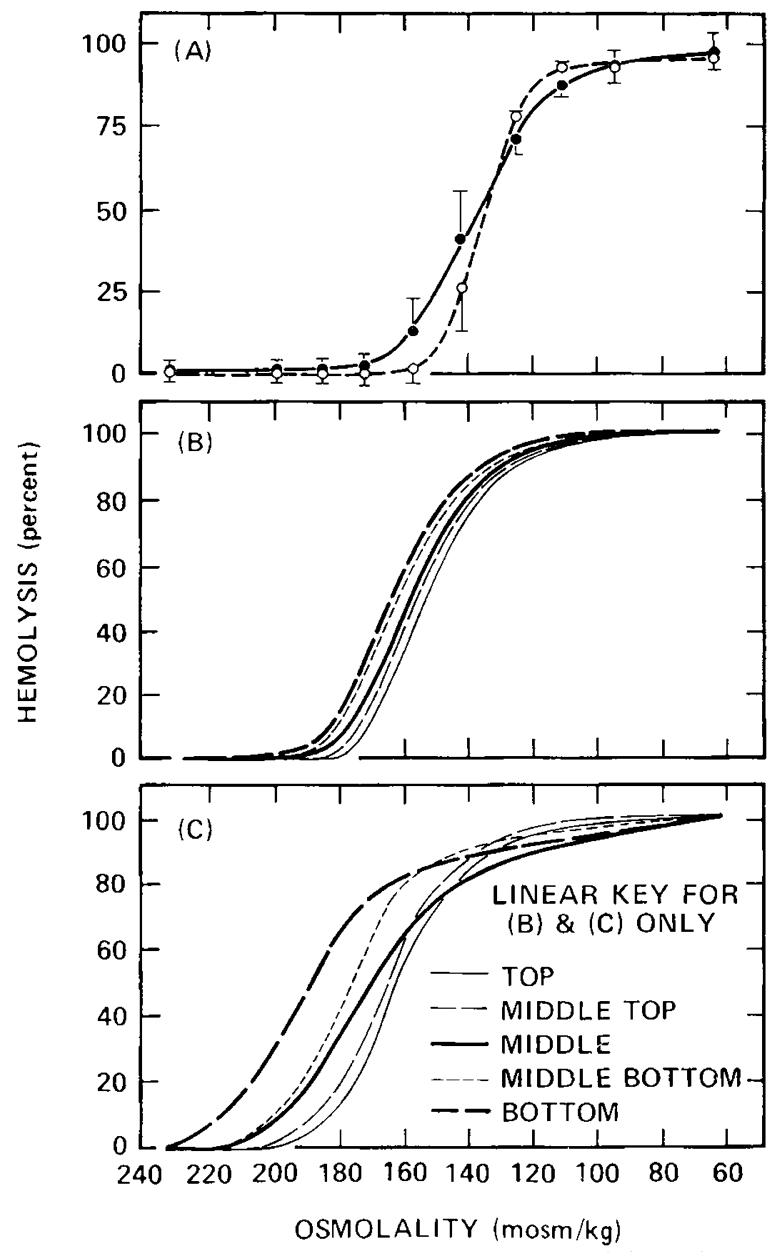

Fig. 1. Osmotic fragility of density separated adult and neonatal erythrocytes. $A$, osmotic fragility curves of $(O)$ adult and $(\bullet)$ neonatal red cells. The curves reflect the mean results obtained from 10 adult and 11 neonatal whole blood samples (error bars indicate 2 SDs). $B$ and $C$, osmotic fragility curves of density separated adult $(B)$ and neonatal $(C)$ red cells, studied in parallel in one representative experiment. The curves are fitted by eye to an 11 point osmotic fragility test.

Table 1. Indices of density-separated adult and neonatal erythrocytes*

\begin{tabular}{|c|c|c|c|c|c|c|c|c|c|}
\hline & & \multicolumn{4}{|c|}{ Adult } & \multicolumn{4}{|c|}{ Neonate } \\
\hline & & $\begin{array}{c}\% \\
\mathrm{RBC}\end{array}$ & $\mathrm{MCV}$ & $\mathrm{MCH}$ & $\mathrm{MCHC}$ & $\begin{array}{c}\% \\
\mathrm{RBC} \\
\end{array}$ & $\mathrm{MCV}$ & $\mathrm{MCH}$ & $\mathrm{MCHC}$ \\
\hline Whole blo & & & 90.1 & 30.0 & 33.3 & & 110.2 & 35.8 & 32.5 \\
\hline \multicolumn{10}{|c|}{ Stractan fraction } \\
\hline \multirow[t]{5}{*}{ Top } & 1 & 15 & 94.2 & 30.6 & 32.5 & 31 & 114.9 & 36.3 & 31.6 \\
\hline & 2 & 19 & 93.6 & 30.6 & 32.7 & 25 & 111.1 & 36.1 & 32.5 \\
\hline & 3 & 32 & 91.5 & 30.1 & 32.9 & 22 & 107.1 & 36.3 & 33.9 \\
\hline & 4 & 22 & 90.5 & 30.5 & 33.7 & 13 & 105.2 & 36.2 & 34.4 \\
\hline & 5 & 13 & 89.9 & 31.3 & 34.8 & 19 & 99.5 & 39.1 & 39.4 \\
\hline
\end{tabular}

* $\mathrm{MCV}\left(\mu^{3}\right), \mathrm{MCH}(\mathrm{pg})$, and $\mathrm{MCHC}(\mathrm{g} / \mathrm{dl})$ were determined for whole blood and for five fractions from a discontinuous: Stractan gradient: Between 1.0 and $1.5 \mathrm{ml}$ packed red cells were sepafated on each $10.5 \mathrm{ml}$ gradient: Each of the fractions (1-5) corresponds to an equivalent density in the neonatal and adult gradients. Results shown are a mean of four experiments. 


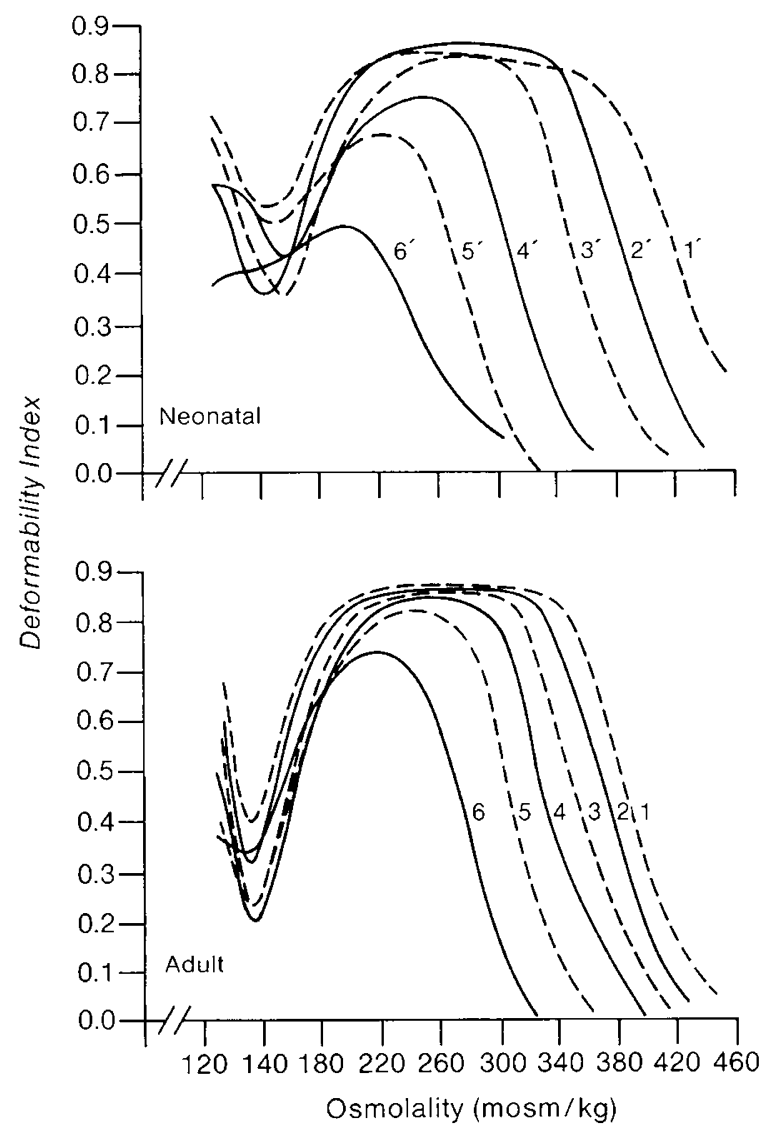

Fig. 2. Osmotic deformability profiles for density separated neonatal erythrocytes. Top panel, neonatal red cells were separated into six fractions on Stractan gradients. (I) $<19 \%$ Stractan, (2) 19-21\% Stractan, (3) $21-23 \%$ Stractan, (4) 23-25\% Stractan, (5) $25-27 \%$ Stractan, (6) $>27 \%$ Stractan. Deformability was measured as a function of increasing osmolality. Bottom panel, equivalent profile for density separated adult red cells.

unseparated neonatal red cells displayed greater heterogeneity than did that of adult cells (Fig. 1). Some neonatal red cells lysed at very high salt concentrations and some were extremely resistant to hypotonic lysis. The source of the heterogeneity can be understood by examining the osmotic fragility curves of the Stractan fractions (Figs. $1 B$ and $C$ ). The top fractions were relatively resistant to hemolysis, and the bottom fractions were fragile. The increase in osmotic fragility which accompanied increasing cell density was particularly noticeable in the densest neonatal red cell population, reflecting the low surface area to volume ratio of these cells.

Osmotic gradient ektacytometry. Figure 2 shows the osmotic gradient ektacytometry profile of subpopulations of neonatal red cells which were separated into six fractions on a Stractan density gradient. The data are from a single experiment, representative of three performed. Results from an equivalent study on adult red cells are also shown for comparative purposes. The $\mathrm{DI}_{\max }$ decreased as the red cells became denser, particularly in the neonatal cell population. In fact, the densest neonatal red cells were almost completely undeformable and it was this population that exhibited the most striking difference from adult red cells. The decrease in $\mathrm{DI}_{\max }$ was consistent with the more pronounced loss of surface area and higher cytoplasmic viscosity (MCHC) noted in older neonatal red cells compared to older adult red cells.

Total phospholipid and cholesterol. Neonatal red cells contain more phospholipid and cholesterol per cell than adult red cells (Table 2). In addition, equivalent volumes of neonatal red cells have more cholesterol but not more phospholipid than their adult counterparts. Thus, the cholesterol to phospholipid ratio is higher in neonatal red cells.

To explore these differences, neonatal and adult red cells were separated on Stractan gradients and the phospholipid and cholesterol content measured in each fraction (Table 3). A modest decline in the amount of both cholesterol and phospholipid per red cell accompanied increasing cellular density. The amount of phospholipid, expressed per ml packed red cells, did not vary with increasing density in both adult and neonatal red cells. In striking contrast, the amount of cholesterol per ml packed adult red cells declined as the cells became more dense, whereas cholesterol content of neonatal red cells remained constant.

Lipid content versus surface area. Lipid content and surface area are compared in Figure 3 which shows the amount of both cholesterol and phospholipid per $\mu^{2}$ membrane surface area in each density fraction of adult and neonatal red cells. The results shown are the average of three experiments. In the adult red cells, the amount of both phospholipid and cholesterol per unit area of plasma membrane remained relatively constant throughout the density gradient. In the neonatal red cells the decrease in surface area exceeded the loss of lipid. Denser, presumably older neonatal red cells contain more lipid relative to their plasma membrane surface area than lighter younger neonatal red cells.

Endocytosis. The loss of surface area without a concomitant loss of lipid led us to evaluate the possibility that the neonatal red cell undergoes in vivo endocytosis throughout its life span. Using phase microscopy, we found that endocytic vacuoles were easily identified in neonatal red cells. The number of neonatal red cells containing enlarged vacuoles increased in parallel with increasing density of the fraction (Table 4). The relatively large size of some of these vacuoles is shown in Figure 4. In contrast, no endocytic vacuoles were seen in the light fractions of adult $\mathrm{RBC}$ and the few vacuoles seen in adult dense fractions were much smaller than those shown in Figure 4.

Phospholipid composition. Analysis of the major classes of phospholipid (Table 5), demonstrated that the ratio of SM to PC was higher in neonatal than adult red cells $(0.89$ versus 0.81$)$. The percentages of PS and PC were lower in neonatal than in adult red cells, while those of PE and SM were the same. The percentage of each of the lipid classes was also compared in the top and bottom fractions of neonatal red cells (Table 5). Dense neonatal red cells contained significantly more SM than light neonatal red cells. No significant difference was observed in the relative percentage of $\mathrm{PC}, \mathrm{PE}$, or PS between the top and bottom fractions.

Phospholipid asymmetry. To investigate the organization of membrane phospholipids, red cells were treated with phospholipase $A_{2}$ alone or with phospholipase $A_{2}$ followed by sphingomyelinase $\mathrm{C}$. Under these conditions, only phospholipids in the outer

Table 2. Phospholipid and cholesterol levels in adult and neonatal erythrocytes*

\begin{tabular}{|c|c|c|}
\hline & Adult & Neonate \\
\hline $\begin{array}{l}\text { Phospholipid } \\
\mu \mathrm{g} / 10^{8} \mathrm{RBC} \\
\mathrm{mg} / \mathrm{ml} \mathrm{RBC}\end{array}$ & $\begin{array}{c}31.9 \pm 3.3(n=31) \\
3.55\end{array}$ & $\begin{array}{c}40.0 \pm 7.1(n=26) \\
3.49\end{array}$ \\
\hline $\begin{array}{l}\text { Cholesterol } \\
\mu \mathrm{g} / 10^{8} \mathrm{RBC} \\
\mathrm{mg} / \mathrm{ml} \mathrm{RBC}\end{array}$ & $\begin{array}{c}13.9 \pm 1.1(n=20) \\
1.41\end{array}$ & $\begin{array}{c}18.5 \pm 3.0(n=18) \\
1.66\end{array}$ \\
\hline $\mathrm{C} / \mathrm{P}$ & 0.86 & 0.92 \\
\hline
\end{tabular}

* Total lipid phosphorus and cholesterol content were determined in red cell preparations from which white cells were removed. Lipid analysis was performed on a known number of red cells (approximately $2 \times 10^{9}$ ) and results expressed as $\mu \mathrm{g}$ lipid $/ 10^{8}$ red cells. The same data were expressed as $\mathrm{mg}$ lipid/ml packed red cells, calculated from the red cell count and a spun hematocrit determined on each fraction. $\mathrm{C} / \mathrm{P}=$ mole cholesterol/mole phospholipid. 
Table 3. Phospholipid and cholesterol levels in density-separated adult and neonatal red cells*

\begin{tabular}{|c|c|c|c|c|c|c|c|c|}
\hline & & \multicolumn{3}{|c|}{ Phospholipid } & \multicolumn{2}{|c|}{ Cholesterol } & \multirow[b]{2}{*}{$\mathrm{C} / \mathrm{P}$} & \multirow[b]{2}{*}{$p$} \\
\hline & & $\mu \mathrm{g} / 10^{8} \mathrm{RBC}$ & $\mathrm{mg} / \mathrm{ml} \mathrm{RBC}$ & $p$ & $\mu \mathrm{g} / 10^{8} \mathrm{RBC}$ & $\mathrm{mg} / \mathrm{ml} \mathrm{RBC}$ & & \\
\hline \multicolumn{9}{|l|}{ Adult } \\
\hline $\mathrm{RBC}$ & & $32.0 \pm 1.94$ & 3.54 & 0.01 & $12.9 \pm 0.91$ & 1.43 & 0.81 & $<0.02$ \\
\hline $\mathrm{RBC}+\mathrm{Str}$ & & $34.1 \pm 0.96$ & 3.74 & 0.55 & $13.4 \pm 0.63$ & 1.47 & 0.79 & $<0.002$ \\
\hline \multicolumn{9}{|c|}{ Stractan fraction } \\
\hline \multirow[t]{4}{*}{ Top } & 1 & $33.5 \pm 6.39$ & 3.53 & 0.32 & $14.0 \pm 3.71$ & 1.48 & 0.77 & 0.11 \\
\hline & 2 & $29.2 \pm 4.99$ & 3.16 & $<0.03$ & $13.3 \pm 1.14$ & 1.44 & 0.89 & $<0.04$ \\
\hline & 3 & $30.1 \pm 1.54$ & 3.28 & $<0.002$ & $13.1 \pm 1.04$ & 1.43 & 0.86 & 0.02 \\
\hline & 4 & $28.1 \pm 4.02$ & 3.10 & 0.14 & $11.5 \pm 0.68$ & 1.27 & 0.81 & 0.02 \\
\hline Bottom & 5 & $29.7 \pm 1.56$ & 3.30 & 0.54 & $11.5 \pm 2.27$ & 1.28 & 0.83 & 0.06 \\
\hline \multicolumn{9}{|l|}{ Neonate } \\
\hline $\mathrm{RBC}$ & & $42.0 \pm 4.62$ & 3.37 & & $18.3 \pm 2.21$ & 1.62 & 0.90 & \\
\hline $\mathrm{RBC}+\mathrm{Str}$ & & $38.2 \pm 3.35$ & 3.40 & & $16.7 \pm 0.42$ & 1.49 & 0.87 & \\
\hline \multicolumn{9}{|c|}{ Stractan fraction } \\
\hline \multirow[t]{4}{*}{ Top } & 1 & $39.7 \pm 8.67$ & 3.37 & & $19.7 \pm 1.20$ & 1.67 & 0.87 & \\
\hline & 2 & $37.0 \pm 5.97$ & 3.24 & & $16.5 \pm 1.35$ & 1.45 & 0.91 & \\
\hline & 3 & $37.9 \pm 2.30$ & 3.37 & & $17.3 \pm 1.44$ & 1.54 & 0.94 & \\
\hline & 4 & $37.0 \pm 9.32$ & 3.44 & & $16.3 \pm 1.70$ & 1.52 & 0.84 & \\
\hline Bottom & 5 & $34.2 \pm 8.71$ & 3.35 & & $16.3 \pm 1.35$ & 1.60 & 0.92 & \\
\hline
\end{tabular}

* Total lipid phosphorus and cholesterol content was determined in five of the experiments described in Table 2. The gradients were identical to those described in Table 1.
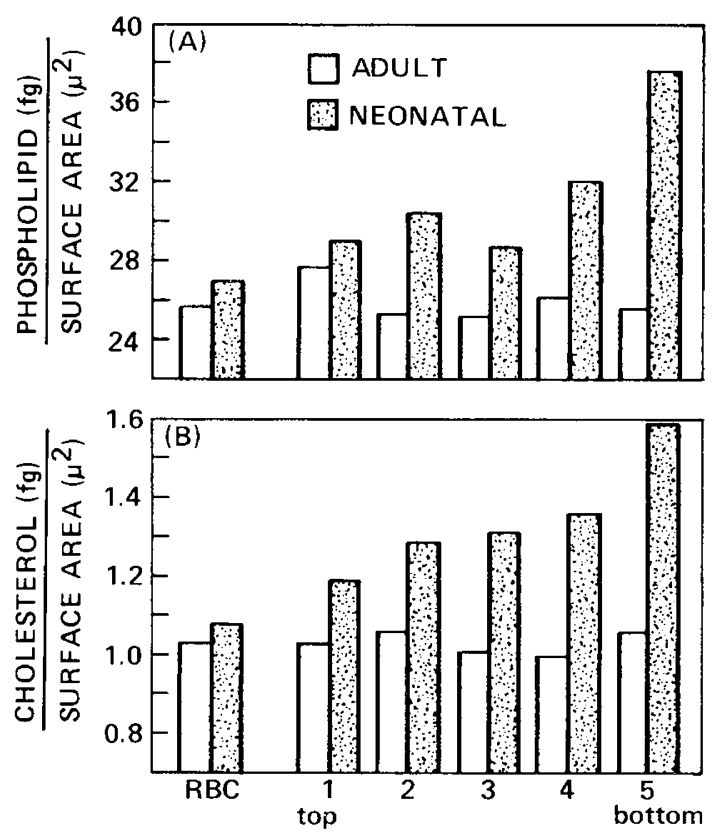

STRACTAN FRACTION

Fig. 3. Lipid per surface area of density separated adult and neonatal erythrocytes. Lipid measurements from three representative experiments were compared to surface area measurements from Reference 5. Adult red cells are indicated by the open bars and neonatal red cells are indicated by the shaded bars.

leaflet of the lipid bilayer are degraded. The results are shown in Table 6. In both neonatal and adult RBC, the addition of sphingomyelinase $C$ produced more extensive degradation of $\mathrm{PC}$ and $\mathrm{PE}$ than the use of phospholipase $\mathrm{A}_{2}$ alone. With both treatments, significant differences in $\mathrm{PC}$ and $\mathrm{PE}$ degradation were observed between neonatal and adult red cells. Neonatal red cells showed less PC degradation and more PE degradation than adult cells. PS degradation was not detected in either adult or neonatal cells (data not shown).
Table 4. Spontaneous endocytic vacuoles (\% of $R B C$ containing vacuoles)*

\begin{tabular}{ccc}
\hline $\begin{array}{c}\text { Stractan } \\
\text { density } \\
\text { fraction } \\
(\text { Stractan \%) }\end{array}$ & $\begin{array}{c}\text { Adult RBC } \\
(\%)\end{array}$ & $\begin{array}{c}\text { Neonatal } \\
\text { RBC }(\%)\end{array}$ \\
\hline $18-19$ & & 1.3 \\
$20-21$ & 0 & 0.8 \\
22 & 0 & 2.3 \\
23 & 0 & 6.9 \\
$24-25$ & 0 & 5.6 \\
$26-27$ & 1.3 & 12.5 \\
$28-29$ & & 10.4 \\
\hline
\end{tabular}

* This is one of three similar experiments. Adult and cord RBC were separated in parallel on Stractan gradients; the fractions were harvested and washed free of Stractan. Two $\mu \mathrm{l}$ of RBC suspension were placed in $10 \mu \mathrm{l}$ of $\mathrm{H}_{2} \mathrm{O}$ on a glass slide and a minimum of 200 lysed $\mathrm{RBC}$ were examined by phase $\mathrm{e}^{-3}$ microscopy $(\times 1000)$ and the number of cells containing the relatively large phase visible vacuoles was recorded.

\section{DISCUSSION}

The drastic loss of surface area which occurs over the life span of the neonatal red cell indicates that its membrane undergoes much more extensive remodeling than the membrane of the adult red cell. Our previous work showed that the plasma membrane surface area of the densest ("old") neonatal red cells was $28 \%$ less than that of the most buoyant ("young") red cells while the equivalent reduction in adult red cell surface area was only $12 \%$ (5). The SAI, which is the ratio between the actual cell surface area and the surface area of a sphere of comparable volume $(3,17)$, was only 1.08 in the densest neonatal cells, indicating that they were essentially incapable of swelling without lysing. In the current report we demonstrate the profound implications of such a reduction in SAI for cell deformability using the ektacytometer. The densest neonatal red cells were far less deformable than any other subpopulation of either neonatal or adult red cells. Red cell deformability is determined by cytoplasmic viscosity as well as by surface area to volume relationships. Thus, the high cytoplasmic viscosity of the densest neo- 
natal cells, as reflected by their high $\mathrm{MCHC}$, must also have contributed to their rigidity. The mechanism for such cellular dehydration is unclear and is the subject of current investigation.

In the mature adult red cell, lipid content directly reflects the amount of plasma membrane, since nuclear and organelle membranes are no longer present. It was therefore of considerable interest that measurements of total cholesterol and phospholipid in density separated neonatal red cells showed only the same modest decline observed in density separated adult cells. This was in sharp contrast to the marked decline in plasma membrane surface area of neonatal cells measured by the critical hemolytic volume method (5). To account for the discrepancy, we postulated that some of the lipid in neonatal cells is not on the exterior of the cell but is conserved in internalized endocytic vacuoles. In fact, we observed such vacuoles with increasing frequency in the higher density neonatal cells, as the discrepancy between total lipid and surface area increased. Thus, in vivo endocytosis may occur throughout the life span of the cell. This would be consistent with the enhanced drug-induced (5) and receptor-mediated endocytosis $(6,7)$ exhibited by neonatal red cells in vitro.

Because prior studies have shown that endocytosis is accompanied by lipid changes $(23,25)$ but not by protein changes (Schrier SL, unpublished observations) we examined neonatal red cell membrane lipids in considerable detail. Our data agree with earlier reports that the neonatal red cell has a slightly higher cholesterol to phospholipid ratio and a higher sphingomyelin to $P C$ ratio than the adult red cell $(10,11,26)$. Neonatal red cell

Fig. 4. Internal vacuoles in dense neonatal erythrocytes. Partially lysed neonatal red cells from Stractan fraction 5 were photographed under phase optics $(\times 1000)$.

Table 5. Phospholipid composition of young and old neonatal erythrocytes*

\begin{tabular}{ccccc} 
& & \multicolumn{3}{c}{ Neonatal RBC } \\
\cline { 3 - 5 } Composition & Adult RBC & Unfractionated & Young & Old \\
\hline \%PC & $31.0 \pm 2.0$ & $28.7 \pm 1.5$ & $29.6 \pm 1.2$ & $28.5 \pm 1.8$ \\
\%SM & $24.8 \pm 2.7$ & $25.5 \pm 3.4$ & $28.7 \pm 3.2$ & $32.4 \pm 1.3 \dagger$ \\
\%PE & $27.5 \pm 2.1$ & $28.3 \pm 2.4$ & $28.1 \pm 4.3$ & $25.4 \pm 1.9$ \\
\%PS & $16.2 \pm 3.3$ & $13.4 \pm 1.0 \pm$ & $14.9 \pm 2.3$ & $13.5 \pm 1.3$ \\
$n$ & & 7 & & \\
\hline
\end{tabular}

* Phospholipid composition of young and old neonatal red cells. Neonatal red cells were separated on Stractan gradients into top and bottom fractions each containing approximately $10-15 \%$ of the total red cells. Composition was determined by two dimensional thin-layer chromatography of the lipid extracts.

+ Young versus old $p<0.04$.

$\$$ Adult versus neonatal $p<0.005$.
Table 6. Accessibility of phospholipids of adult and neonatal erythrocytes by phopholipase $A_{2}$ and sphyngomyelinase $C^{*}$

\begin{tabular}{cccc}
\hline \multicolumn{3}{c}{$\%$ Degradation } & \\
PC & PE & $\%$ Hemolysis \\
\hline
\end{tabular}

\begin{tabular}{lccc}
\hline Phospholipase $\mathrm{A}_{2}$ & & & \\
$\quad$ Adult $(n=4)$ & $59 \pm 1.3$ & $10 \pm 1.7$ & $1.5 \pm 0.3$ \\
Neonate $(n=6)$ & $52 \pm 2.1$ & $16 \pm 2.9$ & $1.2 \pm 0.4$ \\
& $(p<0.01)$ & $(p<0.02)$ & $(\mathrm{NS})$ \\
Phospholipase $\mathrm{A}_{2}$ and & & & \\
$\quad$ sphingomyelinase C & & & \\
Adult $(n=4)$ & $73 \pm 3.1$ & $26 \pm 1.7$ & $2.0 \pm 0.4$ \\
Neonate $(n=6)$ & $64 \pm 8.9$ & $34 \pm 4.0$ & $5.0 \pm 0.7$ \\
& $(p<0.01)$ & $(p<0.05)$ & $(p<0.02)$ \\
\hline
\end{tabular}

* Red cells from adults and newborns were incubated either with phospholipase $\mathrm{A}_{2}$ for $2 \mathrm{~h}$ at $37^{\circ} \mathrm{C}$ or with phospholipase $\mathrm{A}_{2}$ for $1 \mathrm{~h}$ and then sphingomyelinase $C$ for an additional hour. The percentage of the total amount of each lipid class which was degraded by the enzymes is shown.

membranes have also been reported to have more PI (27) and greater amounts of a lipid fraction which contains both PS and PI (10). We observed a small increase in PS but did not attempt to assess PI. Such measurements would be worthwhile, since PI metabolism has been implicated in the modulation of cytoskeletal associations (28) and in red cell shape change (29).

The different patterns of phospholipid degradation and differences in susceptibility to phospholipase-induced hemolysis noted in neonatal and adult red cells appear to reflect subtle differences in the transmembrane distribution and the lateral organization (domains) of membrane phospholipids between these two types of cells. The concept that membrane lipids are organized in domains has been gaining acceptance in the last few years $(23$, 30-32). The differences in the phospholipid degradation patterns between adult and neonatal red cells may arise in part from receptor-mediated endocytosis in neonatal red cells. Such differences bear some similarity to the differences between normal and primaquine-treated normal cells noted after drug-induced endocytosis (23). Differences in lipid-protein interactions are also suggested, although not defined by these experiments. Thus in addition to a shortened life span, an exaggerated heterogeneity, increased spontaneous endocytosis, and a drastic loss in surface area resulting in increased cell rigidity, the neonatal red cell has as yet unexplained alterations in the susceptibility of the phospholipid bilayer to lipases. The nature of the relationship of these lipid changes to the life span of the neonatal red cell and to the maturation of the red cell throughout gestation remains for future analysis.

Acknowledgments. The authors thank Maggie Yee for technical assistance and Jane Lee for typing the manuscript.

\section{REFERENCES}

1. Pearson HA 1967 Life-span of the fetal red blood cell. J Pediatr 70:166-171

2. Matovcik LM, Mentzer WC 1985 The membrane of the human neonatal red cell. In: Schrier SL (ed) Clinics in Haematology. WB Saunders, London, pp 203-221

3. Linderkamp O, Meiselman HJ 1982 Geometric, osmotic and membrane mechanical properties of density-separated human red cells. Blood 59:1121 1127

4. Linderkamp O, Wu PYK, Meiselman HJ 1983 Geometry of neonatal and adult red blood cells. Pediatr Res 17:250-253

5. Matovcik LM, Junga IG, Schrier SL 1985 Drug induced endocytosis and neonatal erythrocytes. Blood 65:1056-1063

6. Schekman R, Singer J 1976 Clustering and endocytosis of membrane receptors can be induced in mature erythrocytes of neonatal but not adult humans. Proc Natl Acad Sci USA 73:4075-4079

7. Tokuyasu KT, Schekman R, Singer SJ 1979 Domains of receptor mobility and endocytosis in the membranes of neonatal human erythrocytes and 
reticulocytes are deficient in spectrin. J Cell Biol 80:481-486

8. Clark MR, Shohet SB 1985 Red cell senescence. In: Schrier SL (ed) Clinics in Haematology. WB Saunders, London, pp 223-257

9. Corash LM, Piomelli S, Chen HC, Seaman C, Gross E 1974 Separation of erythrocytes according to age on a simplified density gradient. J Lab Clin Med 84:147-151

10. Neerhout RC 1968 Erythrocyte lipids in the neonate. Pediatr Res 2:172-178

11. Hurter P, Schroter W, Schedel I, Gerken G 1970 Phospholipids of red cells and blood plasma in adults, newborns infants and patients with $\mathrm{Rh}$ erythroblastosis. Pediatrics 46:259-266

12. Zwaal RFA, Roelofsen B, Comfuriu P, Van Deenan LLM 1975 Organization of phospholipids in human red cell membranes as detected by the action of various purified phopholipases. Biochim Biophys Acta 406:83-86

13. Groner W, Mohandas N, Bessis M 1980 New optical technique for measuring erythrocyte deformability with the ektacytometer. Clin Chem 26:1435-1442

14. Mohandas N, Clark MR, Jacobs M, Shohet SB 1980 Analysis of factor regulating erythrocyte deformity. J Clin Invest 66:563-573

15. Beutler E, West C, Blume K-G 1976 The removal of leukocytes and platelets from whole blood. J Lab Clin Med 88:328-333

16. Mohandas N, Clark MR, Kissenger S, Bayer C, Shohet SB 1980 Inaccuracies associated with the automated measurement of mean cell hemoglobin concentration in dehydrated cells. Blood 56:125-128

17. Sutera SP. Gardner RA, Boylan CW, Carroll GL, Chang KC, Marvel JS, Kilo C, Gonen B, Williamson JR 1985 Age-related changes in deformability of human erythrocytes. Blood 65:275-282

18. Clark MR, Mohandas N, Shohet SB 1983 Osmotic gradient ektacytometry: comprehensive characterization of red cell volume and surface maintenance. Blood 61:899-910

19. Dacie J 1954 The Hemolytic Anemias, 1st ed. Grune and Stratton, New York
20. Rose HG, Oklander M 1965 Improved procedure for the extraction of lipids from human erythrocytes. J Lipid Res 6:428-431

21. Bottcher CJF, van Gent CM, Pries C 1961 A rapid and sensitive sub-microphosphorus determination. Anal Chim Acta 24:203-208

22. Zlatkis A, Zak B, Boyle AJ 1953 New method for direct determination of serum cholesterol. J Lab Clin Med 41:486-492

23. Schrier SL, Chiu D, Yee M, Sizer K, Lubin B 1983 Alteration of the phospholipid bilayer of human red blood cells during drug-induced endocytosis. J Clin Invest 72:1698-1705

24. Lubin B, Chiu D, Bastacky J, Roelofsen B, Van Deenan LLM 1981 Abnormalities in membrane phospholipid organization in sickled erythrocytes. $\mathbf{J}$ Clin Invest 67:1643-1649

25. Gupta CM, Mishra GC 1981 Transbilayer phospholipid asymmetry in Plasmodium knowlesi infected host cell membrane. Science 212:1047-1049

26. Crowley J, Ways P, Jones JW 1965 Human fetal erythrocyte and plasma lipids. J Clin Invest 44:989-998

27. Hollan SR, Szeleny JG, Brever JH, Medgyesi GA, Soter VN 1967 Structural and functional differences between human fetal and adult erythrocytes. Haematology 1:409-420

28. Sheetz MP, Febbrorlello P, Koppel DE 1982 Triphosphoinositide increases glycoprotein lateral mobility in erythrocyte membranes. Nature 296:91-93

29. Ferrell JE, Huestis WH 1984 Phosphoinositide metabolism and the morphology of human erythrocytes. J Cell Biol 98:1992-1998

30. Marinetti GV, Cattieu K 1982 Asymmetric metabolism of phosphatidylethanolamine in the human red cell membrane. J Biol Chem 257:245-248

31. Shukla SD, Hanahan DJ 1982 Identification of domains of phosphatidylcholine in human erythrocyte plasma membranes. J Biol Chem 257:2908-2911

32. Storch J, Kleinfeld AM 1985 The lipid structure of biological membranes Trends Biochem Sci 10:418-421 